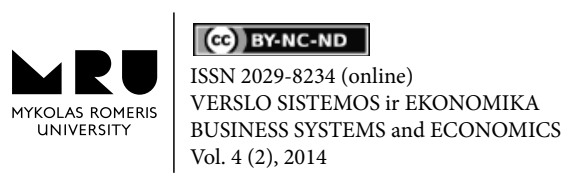

\title{
SUSIJUNGIMUS IR İSIGIJIMUS BANKININKYSTĖS SEKTORIUJE LEMIANČIŲ VEIKSNIŲ KOMPLEKSINIS VERTINIMAS
}

\author{
Lina NOVICKYTÉ \\ Vilniaus universitetas, Ekonomikos fakultetas \\ Saulètekio al. 9, LT-10222 Vilnius, Lietuva \\ Elektroninis paštas: lina.novickyte@ef.vu.lt \\ doi:10.13165/VSE-14-4-2-05
}

Santrauka. Globalizacija, bankų konsolidacija, pasaulinè finansų krizė pastaraisiais dešimtmečiais stipriai paveikè bankininkystè sektorių. Visi šie pokyčiai turèjo įtakos ir sektoriaus plètrai bei jo stabilumui. Šiame straipsnyje nagrinejjami bankininkystės sektoriaus konsolidacinius procesus lemiantys veiksniai ir priežastys. Nustatyti susijungimų ir įsigijimų sandorius bankininkystės sektoriuje lèmę motyvai bei galimas konsolidacijos poveikis finansų sistemai. Atlikus ekspertinị tyrimą sudaryta veiksnių, nuo kurių priklauo susijungimai ir įsigijimai bankininkystès sektoriuje, kompleksinè matrica, kuri apima makro-, mikroveiksnius ir banko vertės nustatymo svarbą.

Reikšminiai žodžiai: susijungimai, ịsigijimai, bankininkystės sektorius, finansų sistema. JEL klasifikacija: G21, G28.

\section{Ivadas}

Bankininkystès ir finansų sektorius yra vienas iš dinamiškiausių ir struktūrinius pokyčius išgyvenančių sektorių. Pasauliniu mastu vykstanti sparti bankų konsolidacija ir koncentracija paskatino aktyvias mokslininkų ir praktikų diskusijas apie koncentracijos ịtaką bankų sistemos efektyvumui ir konkurencijai, šalių finansiniam ir makroekonominiam stabilumui bei ekonomikos augimui. Pažymėtina, kad didelè koncentracija yra labiau toleruojama bankininkystès nei kituose verslo sektoriuose būtent dèl tariamos koncentracijos naudos finansų sistemos stabilumui stiprèti.

Susijungimus ir įsigijimus bankininkystès sektoriuje dažniausiai skatina siekis igyti kuo daugiau svorio tarptautinejje bankinėje erdvèje, eliminuoti iš pelningos veiklos konkurentus, siekti papildomos finansinès naudos akcininkams, teikti daugiau i paslaugų, efektyviai valdyti turimus išteklius. Tokie konsolidaciniai procesai neišvengiamai turi ịtakos ir šalies (regiono) finansų sistemai. Globalizacijos procesų plotmèje sèkminga bankų veikla priklauso nuo tinkamai pasirinktos veiklos strategijos ir veiklos modelio, nuo to, kaip bankai sugeba išnaudoti savo turimą rinkos pranašumą ir įtvirtinti savo pozicijas rinkoje. Bankininkystės sektoriaus svarba ekonomikoje leidžia pagrịsti nagrinejjamos problemos aktualumą ir ištirti bankininkystės sektoriuje vykstančių konsolidacinių procesų veiksnius ir jų poveikị finansų sistemai. 
Taigi šio straipsnio tikslas yra identifikuoti susijungimų ir ịsigijimų sandorius lëmusius ir lemsiančius motyvus bankininkystės sektoriuje ir nustatyti svarbiausius veiksnius, turinčius įtakos šiam procesui.

Straipsnyje taikytas mokslinès literatūros loginès analizės ir sintezės metodas. Siekiant nustatyti esminius veiksnius, lemiančius susijungimus ir ịsigijimus, galimas raidos tendencijas ir įtaką finansų sistemos stabilumui, pasitelktas ekspertinio tyrimo metodas. Jo patikimumas pagrịstas statistiniais reikšmingumo nustatymo metodais. Duomenys ir rezultatai pateikiami paveikslais ir lentelèmis.

\section{Literatūros analizè}

Pastaraisiais dešimtmečiais susijungimų ir ịsigijimų sandoriai, jų rezultatai buvo analizuojami ir ekonomikos teorijos, ir empirinių tyrimų plotmèje. Iš pradžių sandorių analizė rèmèsi JAV rinkos rezultatais, vèliau pradèta vertinti ir Europos erdvèje vykusius susijungimus ir ịsigijimus bankininkystės sektoriuje. Euro ịvedimas, teisės aktų, reguliuojančių bankininkystès ir investicijų sriti, igyvendinimas paskatino kurti integruotą rinką, o tai taip pat prisidèjo prie gausesnio tokių sandorių vyksmo bankininkystės srityje. Naujesni tyrimai bankų susijungimų ir ịsigijimų srityje leidžia ịvertinti bankų konsolidacijos poveikị ne tik bankui, jo savininkams, bet ir ịtaką finansų sistemai.

Pabrèžtina, kad susijungimų ir ịsigijimų problematika yra plačiai tirta ir literatūroje yra skiriamos teorijos, aiškinančios šio vyksmo motyvus. Autorius (Harford, 2011), apibendrindamas susijungimų ir ịsigijimų vyksmo motyvus, nurodo, kad susijungimus ir ịsigijimus aiškinantys motyvai ir priežastys gali būti priskirtos neoklasikinès, agentų ir elgsenos teorijoms. Kiti mokslininkai (Piesse, Lee, Lin, Kuo, 2013), analizuodami susijungimų ir ịsigijimų motyvus, skiria 8 teorijas (hipotezes), kuriomis yra aiškinamas susijungimų ir ịsigijimų vyksmas rinkoje. Novickyte, Saikevičius (2013) nurodo, kad literatūroje iškeltos hipotezės kartais susipina, todèl jas priskyre vyraujančioms teorijoms (žr. 1 pav.). Neoklasikine teorija aiškinami ir grindžiami susijungimai ir ịsigijimai, kuriuos sukelia ekonominiai sutrikimai, dèl kurių vyksta ekonomikos sektoriaus pertvarkymas. Teigiama, kad rinkoje įvyksta i̇monès veiklos rezultatų gerinimas ir (ar) motyvacija atlikti veiklos perskirstymą naudojant susijungimų ir įsigijimų sandorius, kai ekonomikoje susiformuoja technologiniai, reguliavimo arba ekonominiai šokai. Agentų teorija yra aiškinamas įmonès savininkų ir jos vadovų ryšys. Ja remiantis egzistuoja dvilypis konfliktas tarp įmonės savininkų ir įmonei vadovaujančių asmenų: pirmu atveju - yra skirtinga akcininkų ir vadovų įmonei nustatytų tikslų ir uždavinių samprata bei jų igyvendinimas, antru atveju - abi pusès skirtingai vertina riziką.

1 pav. Susijungimų ir ịsigijimų sandorių sudarymą aiškinančios teorijos
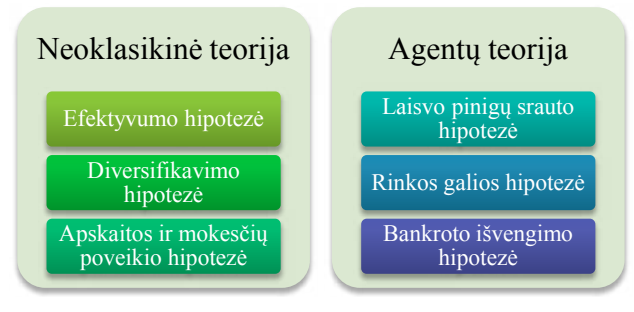

Elgsenos teorija

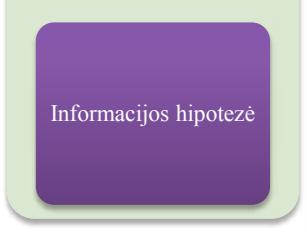

Šaltinis: Novickytė, Saikevičius, 2013 
Paminètinas ir vienas iš pagrindinių tyrimų, nagrinėjančių elgsenos teorijos įtaką susijungimų ir įsigijimų vyksmui (Roll 1986). Mokslininkas padarè išvadą, kad susijungimai ivvyksta paskatinti vadovų puikybès (angl. hubris). Tai patvirtina ir vèlesni (Dermine, 1999) tyrimai: autorius nurodo ir "puikybès“ veiksni, ir skiria dar vieną - „ramaus gyvenimo“. Šaltinyje teigiama, kad dèl masto ekonomijos gaunamas didesnis banko pelnas ir igyta rinkos galia banko vadovams užtikriną „ramų gyvenimą“, nes tokie veiklos rezultatai leidžia vadovams mokèti didesnị atlygi, gauti papildomų premijų ir taip sumažinti savo pareigų praradimo riziką. „Puikybès“ hipotezè teigia, kad per didelè vadovų arogancija ir pasitikejjimas savimi sudaro sąlygas banko vadovams pervertinti bankų susijungimo / ịsigijimo naudą ir tai lemia, jog gali būti permokèta už issigyjamą kitą banką.

Kai kurie tyrimai (Berger, Deyoung, Genay, Udell, 2000; Possible Effects of EMU on the EU Banking Systems in the Medium to Long Term, 1999) nurodo, kad daugiausia banku konsolidaciją Europoje ir pasaulyje lèmè veiklos efektyvumo didinimas, kai siekiama jungti kelis bankus ar kitas finansų institucijas ị vieną darinị, kuris, pasinaudodamas savo dydžiu, sugebedavo klientams paslaugas teikti pigiau, o kartu buvo optimizuojamas naujo darinio banko ar kitos finansų institucijos - filialų, atstovybių tinklas. Tyrèjas (Heffernan, 2005) bankų susijungimų ir įsigijimų priežastis skirsto ị tris kategorijas: akcininkų turto / grąžos maksimizavimas, banko vadovų savanaudiškų tikslų siekimas, kiti veiksniai (padidejjusi nebankinių paslaugų dalyvių konkurencija; bankų teikiamų paslaugų plètra, didinanti bankų nebalansinių straipsnių rodiklius; naujovès ir informacinių technologijų plètra bankininkystès sektoriuje, kuri padeda siekti veiklos sąnaudų optimizavimo, pajamų didinimo ir generuoja papildomas pajamas iš banko teikiamų paslaugų naudojant finansines inovacijas), kurie sukuria palankią aplinką vykti susijungimų ir įsigijimų sandoriams.

Kiti autoriai (Dermine, 1999; 2002; Hernando, Nieto, Wall, 2009) teigia, kad yra ir kitų ìvairių priežasčių, kurios skatina vykti susijungimų ir įsigijimų sandorius bankų sektoriuje. Apskritai tokius sandorius lemia igyjamos įmonės akcininkų gerovès didinimas. Vis dèlto yra išskiriama pagrindinių 10 priežasčių, kurios lemia susijungimų ir ịsigijimų sandorių sudarymą bankininkystès sektoriuje: sąnaudomis pagrịsta masto ekonomija, turimu prekès ženklu pagrịsta masto ekonomija, pajamomis grịsta masto ekonomija, saugumu grịsta masto ekonomija, sąnaudų ekonomija, pardavimais grindžiama ekonomija, finansine diversifikacija grịsta ekonomija, X efektyvumas, rinkos galia, gynyba pagrịsta masto ekonomija.

Taip pat nurodoma (Lambkin, Muzellec, 2008), kad konsolidaciją lemia makroekonominiai (didejjanti globalizacija ir tarptautinès finansų sistemos, kapitalo judejimo liberalizavimas, finansinis reguliavimas šalių viduje, technologijų pažanga ir didesnẻ konkurencija) ir mikroekonominiai (paties banko vadovybès sprendimas sujungti arba įsigyti kitą ịmonę, siekiant padidinti arba išlaikyti įmonès vertę bei padidinti konkurencinị spaudimą kitiems rinkos dalyviams) veiksniai.

Nustatyti ir galimi banko vertę lemiantys veiksnai (Dermine, 2009, 2010; „Fitch“ reitingų agentūra, 2012). Veiksnių skaidymas pagal esminius banko veiklos aplinkos kriterijus pateikiamas 2 paveiksle.

Veiksnius galima skirtyti ị banko išorès aplinkos ir vidaus aplinkos veiksnius. Išorès aplinkai galima priskirti makroveiksnius, vidaus aplinkai - mikroveiksnius. Makroveiksniai apimtų aplinką, kurioje veikia bankas (ekonominė situacija, plètros perspektyvos, rinkos reguliavimo ir priežiūros reikalavimai), o mikroveiksniai - tai tiesiogiai paties banko sukurta aplinka (tiek jo valdymo strategija, tiek gebejjimas veikiant rinkoje pasiekti veiklos efektyvumą laikantis nustatytų veiklos ir reguliavimo apribojimų). 
2 pav. Banko vertę kuriantys veiksniai

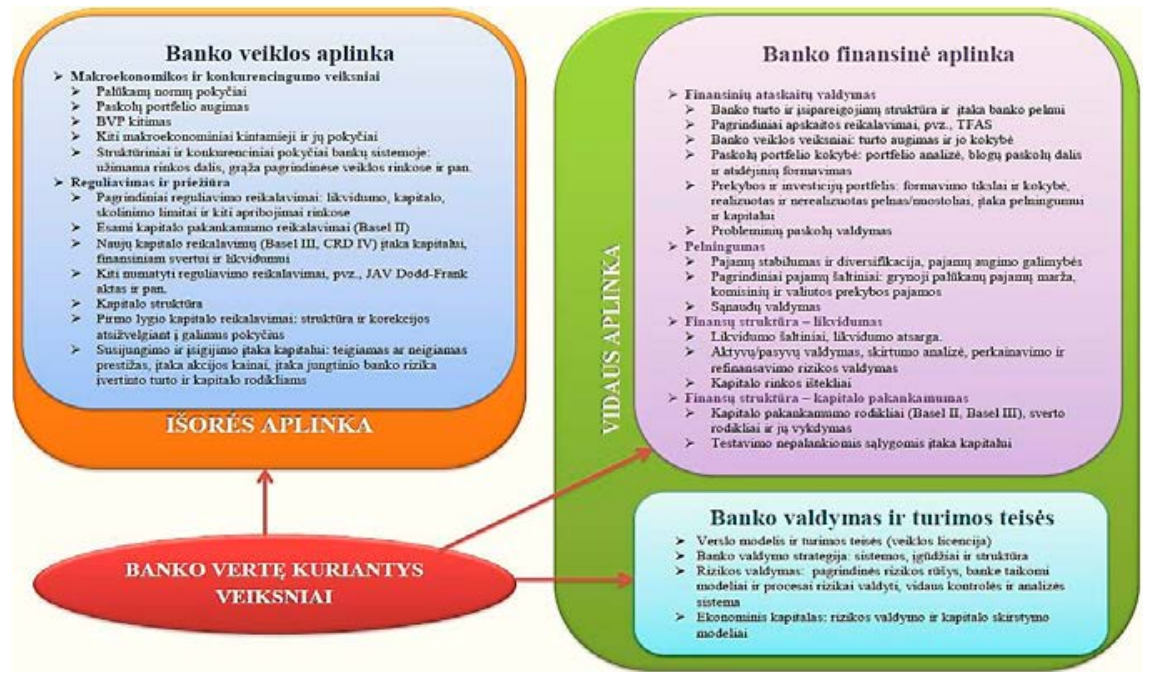

Šaltinis: sudaryta autorès, remiantis (Fitch Training: Bank Valuation, 2012; Dermine, 2009)

Analizuojami bankų ir kitų finansų sektoriaus dalyvių motyvai skirstomi į vidaus ir tarptautinius (Bottiglia, Gualandri, Mazzocco, 2010). Vis dèlto galima nesutikti dèl tam tikrų veiksnių prikyrimo skirtingoms bankų grupėms (žr. 1 lentelę). Reikia pažymėti, kad mažiesiems bankams taip pat rūpi galios statusas ir jo ịtvirtinimas. Mažų bankų grupejje veikiantys bankai taip pat siekia išsiskirti ir būti pirmaujantys savo grupeje, todèl, norèdami igyti daugiau rinkos galios, jie gali jungtis tarpusavyje.

1 lentelè. Bankų ir kitų finansų sektoriaus dalyvių susijungimų ir ịsigijimų sandorių pagrindiniai tikslai

\begin{tabular}{|c|c|c|}
\hline & Vidaus & Tarptautiniai \\
\hline Tarp banky & $\begin{array}{l}\text { Maži ir vidutiniai bankai: } \\
\text { - Veiklos rinkos didinimas } \\
\text { - Masto ekonomija (angl. economies of scale) } \\
\text { - Apskaitos, IT, klientų aptarnavimo, rizikos } \\
\text { valdymo struktūros optimizavimas } \\
\text { - Galimybè išvengti priešiško perèmimo } \\
\text { Stambūs (dideli) bankai: } \\
\text { - Masto ekonomija } \\
\text { - Rinkos dalies didinimas } \\
\text { - Akcininkų grąžos didinimas } \\
\text { - Banko valdymo galios ir statuso įtvirtinimas }\end{array}$ & $\begin{array}{l}\text { Banko valdymo galios ir statuso } \\
\text { ịtvirtinimas } \\
\text { Masto ekonomija tarptautinèse } \\
\text { rinkose } \\
\text { Banko veiklos plètra bendradar- } \\
\text { biaujant su tarptautiniais klien- } \\
\text { tais naujose rinkose }\end{array}$ \\
\hline $\begin{array}{l}\text { Tarp kitu } \\
\text { finansy } \\
\text { sektoriaus } \\
\text { dalyviu }\end{array}$ & $\begin{array}{l}\text { Aprepties ekonomija (angl. economies of scope) } \\
\text { Rizikos diversifikavimas } \\
\text { Paslaugų struktūros optimizavimas } \\
\text { Klientu aptarnavimo tinklo optimizavimas }\end{array}$ & $\begin{array}{l}\text { Institucijos valdymo galios ir } \\
\text { statuso itvirtinimas } \\
\text { Strateginis-geografinis veiklos } \\
\text { diversifikavimas }\end{array}$ \\
\hline
\end{tabular}

Šaltinis: sudaryta autorès, remiantis (Bottiglia, Gualandri, Mazzocco, 2010) 
Be paminètų tradicinių veiksnių, skatinančių susijungimus ir įsigijimus bankininkystès sektoriuje, galima išskirti ir kitas priežastis, kurios sietinos su finansų sektoriaus valdymo pertvarkymu. Vienas iš stabilios finansų sistemos veiklos rodiklių yra sklandi bankininkystès sektoriaus veikla, nes bankai, būdami vieni iš aktyviausių finansų sistemos dalyvių, perskirsto didelę dalị laisvų lěšų ieškodami kuo didesnès grąžos ir ieško galimybių kuo efektyviau valdyti savo išteklius, kuo mažesnėmis išlaidomis pasiekti didesnę naudą savo akcininkams, o tai gali sukelti nepageidaujamų padarinių visam finansų sektoriui. Vienas iš bankų veiklos optimizavimo tikslų - siekti masto ekonomijos įvairiose veiklos srityse. Toks siekis dažniausiai yra pagrindinè priežastis vykti konsolidacijai bankų sektoriuje. Ypač pastaraisiais metais Europoje buvo pastebima bankų susijungimų ir įsigijimų sandorių skaičiaus augimas kaip viena iš galimybių konsoliduoti savo veiklą. Vakarų Europoje tokių sandorių augimas pastebimas vykdant tarptautinius įsigijimo / susijungimo sandorius ịvedus eurą (Uhde, Heimeshoff, 2009).

Išskirti finansų sistemos stabilumui pavojų keliantys vidiniai ir išoriniai šaltiniai gali būti glaudžiai susiję ir su bankų veiklos pokyčiais (Schinasi, 2010). Autorès išskirti verslo strategijos, koncentracijos ir kapitalo pakankamumo vidiniai šaltiniai bei ekonominès aplinkos ir verslo nesèkmès šaltiniai gali būti sietini su susijungimų ir ísigijimų sandoriais bankininkystès sektoriuje.

Verslo strategijos rizika gali būti sietina su banko veiklos pertvarkymu susijungimo ir / ar ịsigijimo būdu. Taigi verslo strategijos rizika glaudžiai susijusi su banko valdymo organų sprendimais plèsti veiklą vidaus ar (ir) užsienio rinkose pasirenkant skirtingą plètros būdą (susijungimas, ịsigijimas, filialo steigimas ir kt.). Nusprendus veiklą plèsti susijungimo ar įsigijimo būdu (ypač vidaus rinkoje), gali didèti koncentracija rinkoje. Todèl verslo plètra glaudžiai susijusi su koncentracijos rizika, nes dažniausiai susijungimai ir įsigijimai bankininkystès sektoriuje padidina koncentraciją rinkoje, o kartais net pats susijungimas ar ìsigijimas yra laikomas koncentracija (Stanikūnas, 2009).

Kapitalo pakankamumo rizika svarbi banko veikloje, nes kapitalas geba absorbuoti galimus veiklos nuostolius. Taip pat didesnis banko kapitalas leidžia bankui igyti rinkoje konkurencinị pranašumą teikiant didesnes paskolas ir taip pritraukiant stambesnių klientų. Ekonominès aplinkos rizika turi ittakos pasirenkant vykdyti susijungimus ar įsigijimus bankininkysteje. Ekonominè šalies padètis turi lemiamą įtaką bankų jungčiai, o stambaus verslo nesèkmè, viena vertus, gali būti laikoma svarbiu veiksniu vykdyti susijungimus dèl „per didelis, kad žlugtų“ koncepcijos, o kita vertus - bankų, kaip sistemiškai svarbių dalyvių, nesèkmè rinkoje atbaido kitus rinkos dalyvius (vietinius ir užsienio) vykdyti bent kokius veiklos pertvarkymo procesus.

Autoriai (Ayadi, Pujals, 2004; Ludwig-Vogler, Giernalczyk, 2010), analizuodami Bazelio bankų kapitalo reguliavimo taisykles teigia, kad vidaus reitingais pagrịstas kapitalo pakankamumo skaičiavimas gali atlaisvinti kapitalą. Mažesnieji bankai, kurie negali taikyti šio modelio, tikètina susidurs su kapitalo poreikio padidejimu ir balanso kokybės suprastèjimu. Tokia situacija gali sudaryti prielaidas pažangesniam bankui ịsigyti tokị banką, kuris negali efektyviai valdyti savo turto ir kapitalo. Veiklos konsolidavimas taip pat galètų būti vienas iš finansų įstaigų konvergencijos etapų, kai institucijos jungiasi ir sudaro universalaus mažmeninio banko modelį, kuris teikia skirtingas paslaugas ịvairiose šalyse.

Vis dèlto ateities perspektyvos vykti susijungimams ir isigijimams bankininkystès sektoriuje nèra aiškios. Galima teigti, kad veiklos funkcijų koncentravimas siekiant efektyvumo, technologijų ir valdymo igūdžių plètra, veiklos diversifikavimas, mažmeninių mokè- 
jimų rinkos derinimas ir integracija gali būti pagrindinės bankų integracijos ir konsolidacijos priežastys ateityje. Ir atvirkščiai, visi ekonominiai ir politiniai svarstymai, sietini su banko dydžio ribojimu vadovaujantis „per didelis, kad žlugtų“ koncepcija, gali paskatinti skaidyti tokias finansines grupes ir būti atvirkščias konsolidacijai procesas. Taigi bankai, noredami didinti savo rinkos vertę, ateityje gali elgtis neatsakingai (ypač turintys didelį finansinị svertą) ir tokiu būdu didinti sisteminę riziką rinkoje.

\section{Tyrimo metodika}

Straipsnyje analizuojama mokslinė problema - bankininkystės sektoriuje vykstantys konsolidaciniai procesai ir juos skatinantys veiksniai, todèl šiai problemai spręsti pasirinktas ekspertų tyrimo metodas. Tyrimo metu gautų rezultatų ịvertinimas leido apibendrinti ir susisteminti plačią kokybinę informaciją bei pasiūlyti bendrą išvadą, kartu prognozuoti galimas šio reiškinio tendencijas. Ekspertinio tyrimo tikslas buvo identifikuoti susijungimų ir ịsigijimų sandorius lèmusius ir lemsiančius motyvus bankininkystès sektoriuje ir nustatyti svarbiausius veiksnius, turinčius poveikị finansų sistemai.

Nustatant ekspertų skaičių vadovaujamasi metodologinėmis prielaidomis, suformuluotomis klasikinèje testų teorijoje. Libby (1978) teigimu, mažos ekspertų grupès gali tiek pat tiksliai įvertinti problemą, kaip ir didelès ekspertų grupés. Taigi tyrimui atlikti buvo sudaryta 9 ekspertų grupé; kiekvieno eksperto svoris buvo vienodas. Remiantis klasikine testų teorija ir neatsižvelgiant $\mathfrak{i}$ kitus statistinius rodiklius, galima teigti, kad 9 ekspertų sprendimų patikimumas yra beveik 90 proc. Atsižvelgiant ị tai, kad ekspertinio tyrimo metodo patikimumas labai priklauso nuo tyrime dalyvaujančių ekspertų kompetencijos, nagrinëjamu atveju tyrimo sistemos subjektai yra akademinès bendruomenès, bankų sistemos priežiūros ir bankų rinkos atstovai, kurie turi patirties ir ypač išmano su ekspertizès objektu susijusią sriti. Akademinei bendruomenei yra priskirti ekspertai, turintys mokslo daktaro laipsnį ir aktyviai atliekantys tyrimus analizuodami bankininkystės sistemos veiklos problemas. Antroji ekspertų grupe - specialistai, dirbantys bankų priežiūros srityje. Šios grupès ekspertai atrinkti pagal papildomus kriterijus, t. y. turintys mokslo daktaro laipsni. Paskutinę ekspertų grupe - komercinių bankų valdymo atstovai. Šiai grupei suformuoti pasirinkti aukščiausio lygio bankų vadovai. Kiekvieną grupę sudare 3 ekspertai. Sudarant klausimyną naudoti Likerto skalès kintamieji, kurios 1 balas reiškè, kad svarstomas kriterijus / aspektas nèra svarbus, t. y. nesvarbiausias analizuojamoje problemoje, o 5 balai nurodè, kad atitinkamas kriterijus yra labai svarbus / svarbiausias.

Kadangi tyrimo metu dalyvavo 9 ekspertai $(n>2)$, tai jų nuomonių suderintumas buvo tikrinamas konkordancijos koeficientu. Konkordancijos koeficientas $W$ yra skaičiuojamas pagal pateiktą (1) formulę (Kendall, 1970):

$$
W=\frac{12 S}{r^{2} \times m\left(m^{2}-1\right)} .
$$

Kendall (1970) ịrodè, jei alternatyvų / kriterijų skaičius pakankamai didelis $(m \geq 7)$, tai konkordancijos koeficiento reikšmingumui tikrinti galima taikyti $\chi^{2}$ kriterijų. Podvezko (2005) pateikia, kad atsitiktinis dydis $\chi^{2}$ yra skaičiuojamas pagal Pirsono formulę: 


$$
\chi^{2}=W \times r(m-1)=\frac{12 S}{r \times m(m+1)} .
$$

Jei apskaičiuota pagal (2) formulę $\chi^{2}$ reikšmė yra didesnè už $\chi_{\text {kritinee }}^{2}$ tai ekspertų vertinimai yra suderinti.

Atliekant ekspertinị tyrimą yra vertinamas klausimyno patikimumas. Klausimyno patikimumu yra laikoma gautų testo rezultatų ir hipotetinių „tikrų“ rezultatų koreliacija. Klausimyno skalès vidiniam nuoseklumui ịvertinti dažniausiai yra naudojamas Cronbacho alfa (angl. Cronbach's alpha) koeficientas. Cronbacho alfa koeficientas skaičiuojamas pagal formulę (Pukenas, 2009; Cronbach, 1951):

$$
\alpha=\left(\frac{k}{k-1}\right) \times\left[1-\frac{\sum_{i=1}^{k} S_{i}^{2}}{S_{p}^{2}}\right] .
$$

(3) formulèje $k$ yra skalès elementų skaičius; $S_{i}^{2}-$ i-tojo skalès elemento dispersija; $S_{p}^{2}$ - bendra skalès dispersija.

Spearmano ir Browno didesnio patikimumo koeficientas (angl. Spearman-Brown stepped-up reliability coefficient) naudojamas ịvertinti atsakymų í atskirus klausimus dispersijų skirtingumą ir skaičiuojamas pagal formulę:

$$
\alpha=\frac{k \times \bar{r}}{1+(k-1) \bar{r}} .
$$

(4) formuleje $\bar{r}$ yra visų ịmanomų atsakymų ị klausimus porų koreliacijos koeficiento vidurkis.

Ekspertinis tyrimas buvo atliekamas $2012 \mathrm{~m}$. birželio-liepos mèn. Ekspertams buvo pateikti pagrindiniai veiksniai / rodikliai, kurie turi būti vertinami vykdant susijungimus ir Ł̇sigijimus bankininkystės sektoriuje mažoje atviroje ekonomikoje, suskirstyti į makroveiksnius ir mikroveiksnius.

\section{Tyrimo rezultatai}

Ekspertams pateiktas klausimynas leido identifikuoti susijungimų ir ịsigijimų sandorius lemsiančius motyvus bankininkystės sektoriuje ir nustatyti svarbiausius veiksnius, lemiančius finansų sistemos stabilumą. Nagrinèjami veiksniai buvo suskirstyti į dvi grupes - makro- ir mikroveiksnius: makroveiksniams priskirti rodikliai apima šalies ekonominius, bankininkystès rinkos valdymo ir bankininkystès rinkos priežiūros reglamentavimo rodiklius; mikroveiksnių grupę sudaro bankų veiklos ir jos kokybės rodikliai.

Nagrinėdami susijungimų ir ịsigijimų sandorių bankininkystès sektoriuje perspektyvas, ekspertai ( $W$ koeficiento reikšmè yra 0,$337 ; \chi^{2}$ yra didesne už $\chi_{\text {kritine, }}^{2}$, y. $102,331>46,1943$; Cronbacho alfa ir Spearmano ir Browno didesnio patikimumo koeficientų reikšmès yra atitinkamai 0,619 ir 0,594$)$ išskyre šiuos pagrindinius veiksnius, turinčius ịtakos konsolidaciniams reiškiniams bankininkystès sektoriuje: banko taikinio ir banko pirkejjo pelningumas ir veiklos efektyvumas, kurie sietini su bankų noru pasinaudoti finansinès sinergijos nauda 
(pajamų sinergija, sąnaudų sinergija, rinkos galios sinergija), banko pirkèjo kapitalo rodikliai, kurie lemia banko galimybę absorbuoti galimus nuostolius, o palankiu ekonomikos ciklo fazės metu - didinti banko paskolų portfelį (žr. 2 lentelę).

Apklaustų grupių ekspertai išskyrẻ paskolų portfelio kokybės rodiklius banko taikinio ir banko pirkejjo šalyse ir naujuosius bankų priežiūros ir reguliavimo reikalavimus, kurie turètų ịtakos susijungimų ir ịsigijimų sandorių bankininkystés sektoriuje vyksmui ir juos lemtų Šie veiksniai yra išsamiai analizuoti ir ịvertinti plačiame mokslinės analizès kontekste (Ingves, 2007; Stichele, 2008; Begg, 2009; Masciandaro, Nieto, Quintyn, 2009; Masciandaro, Pansini, Quintyn, 2011; Ludwig-Vogler, Giernalczyk, 2010; Miklaszewska, 2011; Novickytė, Jasienè, 2011; Novickytè, 2012), nurodant, kad jie gali būti priežastis bankams jungtis (siekti sąnaudų sinergijos, igyvendinti kitus nematerialios sinergijos tikslus).

Ekspertai kaip mažiausiai svarbius veiksnius išskyrè BVP vienam gyventojui, infliacijos dydị šalyje ir paskolų portfelio privatiems asmenims augimą. Pažymètina, kad bankų rinkos ekspertai prie nesvarbių veiksnių priskyrè įejimo į rinką apribojimus, bankų veiklos apribojimus, šalies vyriausybės dalyvavimą valdant bankus ir „per didelis, kad žlugtų“ veiksnius. Akivaizdu, kad perspektyvoje ekspertai, pasirinkdami minètus veiksnius kaip nesvarbius, mato didesnę rinkų integraciją ir suvienodintus bankams taikomus veiklos ribojimo reikalavimus, todèl šie veiksniai neturès didelès įtakos pasirenkant valstybę, kurioje bankai norètų plèsti savo veiklą. Bankų priežiūros ekspertai kaip svarbiausius vertina tuos pačius veiksnius - paskolu portfelio kokybès rodiklius banko taikinio ir banko pirkejjo šalyse ir indèlių draudimo sistemos egzistavimą, kurie, jų nuomone, labiausiai paveiktų konsolidacinius procesus bankininkystès sektoriuje.

2 lentelè. Vidutinė ekspertų nuomonès reikšmè, balais

\begin{tabular}{|l|c|c|c|c|}
\hline \multicolumn{1}{|c|}{ Veiksnys } & $\begin{array}{c}\text { Akademi- } \\
\text { nès } \\
\text { bendruo- } \\
\text { menès } \\
\text { ekspertai }\end{array}$ & $\begin{array}{c}\text { Banku sis- } \\
\text { temos } \\
\text { priežiūros } \\
\text { ekspertai }\end{array}$ & $\begin{array}{c}\text { Banku } \\
\text { rinkos } \\
\text { ekspertai }\end{array}$ & $\begin{array}{c}\text { Visi } \\
\text { ekspertai }\end{array}$ \\
\hline Banko pirkejjo pelningumo rodikliai & 4,33 & 4,33 & 4,67 & $\mathbf{4 , 0 0}$ \\
\hline Banko taikinio pelningumo rodikliai & 4,22 & 4,00 & 4,67 & $\mathbf{4 , 0 0}$ \\
\hline Banko pirkejo kapitalo rodikliai & 4,44 & 4,67 & 4,67 & $\mathbf{4 , 0 0}$ \\
\hline Banko taikinio kapitalo rodikliai & 4,00 & 3,33 & 4,67 & $\mathbf{4 , 0 0}$ \\
\hline Banko pirkejjo veiklos efektyvumo rodikliai & 4,33 & 4,33 & 4,67 & $\mathbf{4 , 0 0}$ \\
\hline Banko taikinio veiklos efektyvumo rodikliai & 4,33 & 3,67 & 4,67 & $\mathbf{4 , 6 7}$ \\
\hline $\begin{array}{l}\text { Koncentracija bankų sektoriuje banko pirkėjo } \\
\text { rinkoje }\end{array}$ & 3,78 & 3,67 & 4,00 & $\mathbf{3 , 6 7}$ \\
\hline $\begin{array}{l}\text { Koncentracija bankų sektoriuje banko } \\
\text { taikinio rinkoje }\end{array}$ & 3,89 & 4,00 & 4,00 & $\mathbf{3 , 6 7}$ \\
\hline Bankų sektoriaus dydis & 3,89 & 4,33 & 4,00 & $\mathbf{3 , 3 3}$ \\
\hline Banko taikinio dydis (turtas, rinkos dalis) & 3,89 & 4,00 & 4,00 & $\mathbf{3 , 6 7}$ \\
\hline Banko pirkejjo dydis (turtas, rinkos dalis) & 3,89 & 4,33 & 4,00 & $\mathbf{3 , 3 3}$ \\
\hline BVP vienam gyventojui banko taikinio šalyje & 3,00 & 3,67 & 2,33 & $\mathbf{3 , 0 0}$ \\
\hline BVP vienam gyventojui banko pirkejo šalyje & 2,78 & 3,00 & 2,33 & $\mathbf{3 , 0 0}$ \\
\hline
\end{tabular}




\begin{tabular}{|c|c|c|c|c|}
\hline $\begin{array}{l}\text { Šalies realaus BVP augimas banko taikinio } \\
\text { šalyje }\end{array}$ & 3,67 & 3,67 & 3,33 & 4,00 \\
\hline $\begin{array}{l}\text { Šalies realaus BVP augimas banko pirkejo } \\
\text { šalyje }\end{array}$ & 3,33 & 3,00 & 3,00 & 4,00 \\
\hline Šalies infliacijos dydis banko taikinio šalyje & 3,11 & 3,33 & 2,33 & 3,67 \\
\hline Šalies infliacijos dydis banko pirkejjo šalyje & 2,89 & 3,00 & 2,00 & 3,67 \\
\hline Reali palūkanų norma banko taikinio šalyje & 3,89 & 4,33 & 3,33 & 4,00 \\
\hline Reali palūkanų norma banko pirkėjo šalyje & 3,56 & 3,67 & 3,33 & 3,67 \\
\hline $\begin{array}{l}\text { Paskolų privačiam sektoriui portfelio augimas } \\
\text { banko taikinio šalyje }\end{array}$ & 3,89 & 4,33 & 4,00 & 3,33 \\
\hline $\begin{array}{l}\text { Paskolų privačiam sektoriui portfelio augimas } \\
\text { banko pirkèjo šalyje }\end{array}$ & 3,33 & 3,33 & 3,67 & 3,00 \\
\hline Grynoji palūkanų marža banko taikinio šalyje & 4,00 & 4,67 & 3,33 & 4,00 \\
\hline Grynoji palūkanų marža banko pirkejo šalyje & 3,56 & 3,67 & 3,00 & 4,00 \\
\hline $\begin{array}{l}\text { Paskolų portfelio kokybès rodikliai banko } \\
\text { taikinio šalyje }\end{array}$ & 4,67 & 4,33 & 5,00 & 4,67 \\
\hline $\begin{array}{l}\text { Paskolų portfelio kokybės rodikliai banko } \\
\text { pirkejo šalyje }\end{array}$ & 4,11 & 3,33 & 5,00 & 4,00 \\
\hline Egzistuojanti šalyje indèlių draudimo sistema & 4,00 & 3,67 & 5,00 & 3,33 \\
\hline İejimo į rinką apribojimai & 3,67 & 3,67 & 4,33 & 3,00 \\
\hline Bankų veiklos apribojimai & 3,89 & 3,67 & 4,67 & 3,33 \\
\hline $\begin{array}{l}\text { Šalies vyriausybés dalyvavimas valdant } \\
\text { bankus (valstybinių bankų egzistavimas) }\end{array}$ & 3,22 & 3,33 & 3,67 & 2,67 \\
\hline Šalies ekonominè laisvè & 3,67 & 3,67 & 4,00 & 3,33 \\
\hline Banko organizacinè kultūra & 3,67 & 3,33 & 4,00 & 3,67 \\
\hline „Per didelis, kad žlugtų“ koncepcija & 3,44 & 4,00 & 4,00 & 2,33 \\
\hline $\begin{array}{l}\text { Nauji (Basel III, CRDIV ir pan.) bankų } \\
\text { priežiūros ir reguliavimo reikalavimai }\end{array}$ & 4,11 & 4,67 & 4,00 & 3,67 \\
\hline
\end{tabular}

Šaltinis: sudaryta autorès

Akademinès bendruomenès ekspertai skiria banko pirkèjo kapitalo rodiklius, grynosios palūkanų maržos banko taikinio šalyje ir naujų bankų priežiūros ir reguliavimo reikalavimų ịtaką susijungimams bankininkystès sektoriuje vykti.

Gauti tyrimo rezultatai leidžia sudaryti turinčių ịtakos susijungimams ir ịsigijimams bankininkystès sektoriuje veiksnių kompleksinę matricą (žr. 3 pav.). Išskirtų veiksnių tolesnis kiekybinis ịvertinimas leistų ịvertinti ex ante ketinamo vykdyti bankų susijungimo ar issigijimo sandorị atsižvelgiant ị sisteminès rizikos lygí. 
3 pav. Susijungimų ir įsigijimų bankininkystės sektoriuje veiksnių kompleksinė matrica

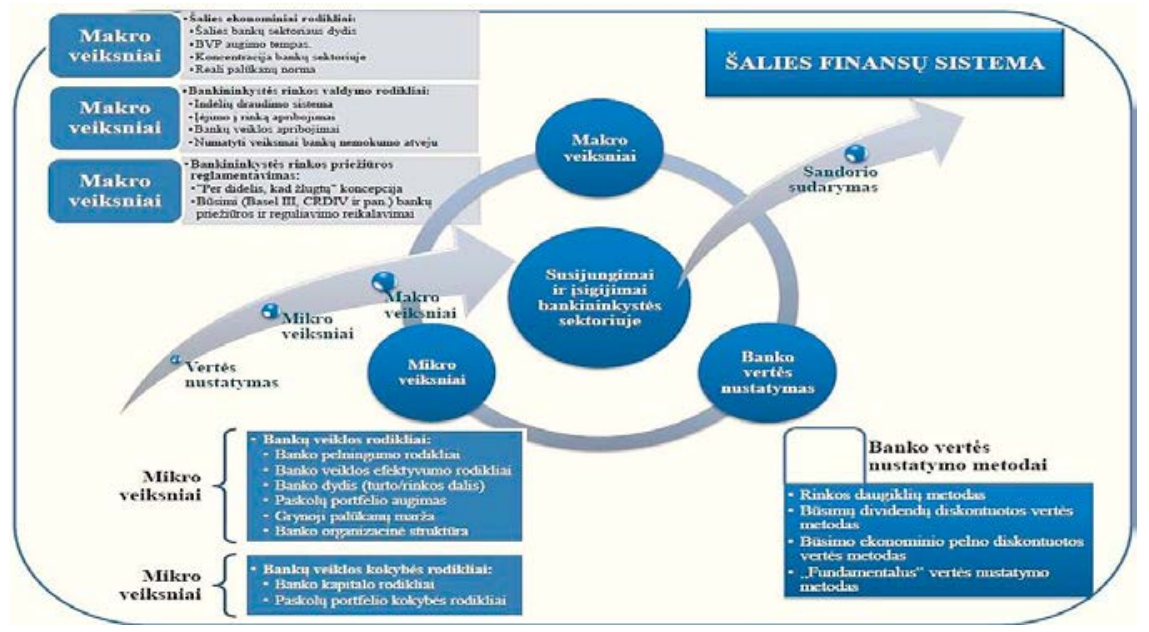

Šaltinis: sudaryta autorès, remiantis tyrimų rezultatais

Pastaba. Pirmoji rodyklè (kairè) sujungia visus veiksnius, skatinančius sudaryti sandorị, o antroji (dešinè) - esant tinkamai veiksnių kombinacijai sudaro prielaidas vykti bankų susijungimų ar ịsigijimų sandoriui; toks sandoris vienareikšmiai turi ịtakos šalies finansų sistemai.

Matrica yra sudaryta iš susijungimus ir ịsigijimus bankininkystės sektoriuje lemiančių veiksnių, kurie suskirstyti į tris grupes:

- Makroveiksniai. Šie veiksniai yra suskaidyti į tris grupes - šalies ekonomikos, bankininkystes rinkos valdymo rodiklius ir bankininkystés rinkos priežiūros reglamentavimo situacijos ịvertinimo dydžius. Išskirti veiksniai leidžia ịvertinti šalies ekonominị potencialą sẻkmingai igyvendinti sandori, taip pat suteikia galimybę jungtiniam bankui prognozuoti savo veiklos perspektyvas. Kartu rodikliai padeda nustatyti konkurencijos bankų sektoriuje pobūdį ir dydį. Pažymètina, kad pagrindiniai šalies ir bankininkystès sektoriaus rodikliai suteikia galimybę bankui pirkèjui įvertinti sudaryto sandorio finansinę naudą, t. y. pirkejjai siekia grązos, optimizuoti veiklą, mažinti patiriamas sąnaudas, plèsti rinkos dalị ir kt. Akivaizdu, kad šalys (ir jų bankų sektorius), pasižyminčios stabiliais rodikliais, yra patrauklios vykti tokiems sandoriams. Taip pat gali būti ir kita pusè - šalies bankų priežiüros specialistai; nagrinėdami ir vertindami pagrindinius rodiklius, jie iš anksto gali numatyti ir valdyti galimus sandorius rinkoje.

Ypač šiuo metu yra svarbu atkreipti dèmesị i pokyčius, kurie vyksta tobulinant bankų priežiüros sistemą. Šie veiksniai bus susijungimų ir ịsigijimų bankininkystès sektoriuje prielaida. Pažymètina, kad papildomi priežiūros reikalavimai ne visada yra teigiamai vertinami bankų savininkų ir jų vadovų. Todèl nesubalansuota griežtejjanti priežiūra gali stabdyti bankų konsolidavimosi norus. Norint nustatyti, ar konsolidavimasis turès teigiamą, ar neigiamą ịtaką rinkai, būtina atlikti pagrịstą tokio sandorio ịvertinimą.

- Mikroveiksniai. Šių veiksnių grupę sudaro bankų veiklos ir jos kokybès rodikliai. Rodiklių analizè suteikia galimybę besijungiantiems bankams ir bankų priežiūros specialistams ịvertinti besijungiančių bankų finansinę būklę, sugebejjimą konkuruoti rinkoje ir vykdyti veiklos riziką ribojančius normatyvus. Taip pat padeda nustatyti besijungiančių bankų 
turto dydị, galimą masto ekonomijos efektą, sinergijos poveikị jungtinio banko rezultatams, ivertinti banko verslo planus, veiklos strategiją.

Šie veiksniai taip pat sudaro prielaidas ịvertinti sandorio naudą po jo sudarymo. Minèta, kad bankas pirkejjas dažniausiai suinteresuotas grąža, todèl galimybès išplèsti rinką, optimizuoti sąnaudas, padidinti pelną - ji visada domina. Priežiūros institucijos, vertindamos šiuos rodiklius, gali juos laikyti kaip išankstinio isspejjimo mechanizmą, kuriuo galima ex ante nustatyti galimas rinkos „perkaitimo“ situacijas ir imtis priemonių, kad sektoriuje nesusidarytų nestabili situacija.

- Banko vertés nustatymo metodai. Ši susijungimus ir ịsigijimus lemianti dalis sietina su pačių bankų savo vertès teisingu nustatymu. Kadangi bankų verslas yra ịvairus ir susijęs su aktyviu rizikos valdymu, nustatyti tikslią banko vertę yra sudètinga. Todèl siūlomi metodai, kurių tinkamas derinys leistų efektyviai nustatyti parduodamo ar / ir perkamo banko vertę. Svarbu paminèti, kad šiuolaikinejje bankininkysteje taikomi įvairūs vertès nustatymo metodai ar jų deriniai. Banko vertès nustatymo procedūra yra sudètingas procesas, apimantis ívairias banko veiklos sritis. Siekiant nustatyti kuo tikslesnę banko vertę, reikètų atlikti turto, ívertinto pagal riziką, vertinimą; nustatyti banko likvidumo šaltinius ir jų ịtaką banko vertei. Šiuolaikinis bankas dažniausiai atlieka universalaus banko funkcijas, todèl, be tradicinių paslaugų (paskolų teikimo ir indèlių prièmimo), jis teikia ir kitas paslaugas, už kurias gauna komisinių pajamas. Taip pat pažymėtina, kad bankų konsolidacija sukuria finansų konglomeratus, kurie pasižymi daug platesniu paslaugų teikimu - turto, gerovès valdymo paslaugos, investicijų valdymas ir kt. Ši veikla dar labiau veikia banko vertės nustatymo procedūras, nes reikia įvertinti atskiro tokio konglomerato padalinio sukuriamą vertę. Pažymėtina, kad susijungimo ar įsigijimo metu susiformavęs prestižas leidžia jungtinio banko vadovybei laviruoti nustatant jo nudèvejjimo laikotarpi, o tai suteikia galimybę valdyti banko pelno rodiklius.

Reikètų paminèti, kad sudaryta veiksnių matrica turi apribojimų. Ji parodo tam tikros situacijos vaizdą, tačiau jos sudedamosios dalys (veiksniai, rodikliai) nèra apibrèžtos ir ịvertintos ribinėmis (aukščiausia / žemiausia) reikšmėmis. Pažymėtina, kad šalys pasižymi skirtingu finansų sistemos dariniu, todèl yra sudètinga nustatyti aiškias ribas, kurias pasiekus bùtų laikoma, kad sandoris pakenktų finansų sistemai, arba, atvirkščiai, sukurtų sektoriui pridètinę vertę. Teigtina, kad ypač šalies priežiūros institucijų specialistai galètų ir turètų nustatyti ribines rodiklių reikšmes ir jomis vadovautis priimdami sprendimus, sietinus su bankininkystès sektoriaus pokyčiais, kurie galimi sudarant susijungimų ir ịsigijimų sandorius.

Todèl sẻkminga visų veiksnių integracija leistų ịvertinti banko susijungimą ar įsigijimą visos finansų sistemos stabilumo kontekste. Pateikta kompleksinė veiksnių matrica gali būti taikoma priežiūros sistemos specialistų, kurie vertina sisteminės rizikos lygį bankų sektoriuje.

\section{Išvados}

Išskirti vieną dominuojančią teoriją ir veiksnius, kurie lemtų susijungimų ir ịsigijimų sandorių sudarymą rinkoje, yra sudètinga. Autorès nuomone, skirtinga šalių ekonominė padėtis, jų išsivystymo lygis lemia ir skirtingus motyvus sudaryti tokius sandorius. Galima teigti, kad pastaruoju metu susijungimų ir ịsigijimų sandorių vyksmą lemia neoklasikinès ir elgsenos teorijos veiksniai. Reikia pažymèti, kad, be racionaliai pagrịstų finansinių motyvų, sandorių sudarymą lemia ir įvairūs elgsenos nuokrypiai.

Remiantis ekspertinio tyrimo duomenimis nustatyta, kad pagrindiniai makroveiksniai, kurie gali lemti susijungimą ir įsigijimą bankininkystès sektoriuje, yra šalies bankų 
sektoriaus dydis, šalies BVP augimo tempas, koncentracija bankų sektoriuje, reali palūkanų norma, indèlių draudimo sistema šalyje, įejimo ị rinką ir bankų veiklos apribojimai, numatyti veiksmai banko nemokumo atveju. Taip pat turi ịtakos nauji bankų sektoriaus priežiūros ir reguliavimo pokyčiai. Analizuojant mikroveiksnius, išskirti tokie bankų veiklos rodikliai - pelningumas, veiklos efektyvumas, banko dydis, paskolų portfelio augimas, palūkanų marža ir bankų veiklos kokybės rodikliai: kapitalo ir paskolų portfelio kokybės. Šie rodikliai yra svarbūs bankui pirkejjui ir bankų priežiūros sistemos dalyviams priimant sprendimą dèl galimo bankų susijungimo ir ịsigijimo. Siekiant visapusiškai įvertinti sandorị, papildomai svarbu atlikti kuo tikslesni banko vertės nustatymą. Galiausiai visų šių veiksnių ir motyvų sintezė leidžia nustatyti galimą banko susijungimo ir ịsigijimo teigiamą sinergijos poveikị bankui pirkejjui ir tokio sandorio įtaką šalies finansų sistemai.

\section{Literatūra}

Ayadi, R., and Pujals, G. (2004). Banking Consolidation in the EU. Brussels: Centre for European Policy Studies.

Begg, I. (2009). Regulation and Supervision of Financial Intermediaries in the EU: The Aftermath of the Financial Crisis. Journal of Common Market Studies, 47(5), 1107-1128.

Berger, N. A., Deyoung, R., Genay, H., and Udell, F. G. (2000). Globalization of Financial Institutions: Evidence from Cross-Border Banking Performance. Brookings-Wharton Papers on Financial Services, 136.

Bottiglia, R., Gualandri, E., and Mazzocco, N. G. (2010). Consolidation in the Financial Industry. Esantis R. Bottiglia, E. Gualandri, N. G. Mazzocco, Consolidation in the European Financial Industry (p. 1-17). Basingstoke: Palgrave MacMillan.

Cronbach, L. J. (1951). Coefficient alpha and the internal structure of tests. Psychometrika, 16(3), 297-334.

Dermine, J. (1999). The Economics of Bank Mergers in the European Union: a Review of the Public Policy Issues. INSEAD Working Paper, 60.

Dermine, J. (2002). European Banking: Past, Present and Future. Fontainebleau: INSEAD.

Dermine, J. (2009). Bank valuation and value-based management: deposit and loan pricing, performance evaluation, and risk management. New York: McGraw-Hill, Inc.

Dermine, J. (2010). Bank Valuation: with an Application to the Implicit Duration of non-Maturing Deposits. International Journal of Banking, Accounting and Finance, 2(1), 1-30. doi:10.1504/ IJBAAF.2010.031573

Fitch Training: Bank Valuation. (2012). Paimta 2012 m. 0520 d. iš Fitch: http://www.fitchtraining.com/ Pdf/brochures/1020-bank-valuation.pdf

Harford, J. (2011). Mergers wawes. Esantis H. K. Kiymaz, The Art of Capital Restructuring: Creating Shareholder Value Through Mergers and Acquisitions (p. 17-37). New Jersey: John Wiley \& Sons, Inc.

Heffernan, S. (2005). Modern Banking. Chichester: John Wiley \& Sons Ltd.

Hernando, I., Nieto, J. M., and Wall, D. L. (2009). Determinants of Domestic and Cross-Border Bank Acquisitions in the European Union. Journal of Banking \& Finance, 33, 1022-1032. doi:10.1016/j. jbankfin.2008.10.017

Ingves, S. (2007). Cross-Border Banking Regulation - A Way Forward: The European Case. International Financial Instability: Global Banking and National Regulation, T. 2, 3-11. Singapore: World Scientific Publishing Co. Pte. Ltd. doi:10.1142/9789812708731_0001

Kendall, M. (1970). Rank correlation methods. London: Griffin.

Lambkin, M., and Muzellec,L. (2008). RebrandingintheBanking IndustryFollowing Mergers and Acquisitions. International Journal of Bank Marketing, 26(5), 328-352. doi:10.1108/02652320810894398

Libby, R., and Blashfield, K. R. (1978). Performance of a composite as a function of a number of judges. Organizational Behavior and Human Performance, 21, 121-129.

Ludwig-Vogler, K., and Giernalczyk, H. (2010). Financial Services: Challenges and Prospects. Munich: EUROFOUND. 
Masciandaro, D., Nieto, M., and Quintyn, M. (2009). Financial Supervision in the EU: Is There Convergence in the National Architectures? Journal of Financial Regulation and Compliance, 86-95.

Masciandaro, D., Pansini, R. V., and Quintyn, M. (2011). The Economic Crisis: Did Financial Supervision Matter? IMF Working Paper, WP/11/261, 48.

Miklaszewska, E. (2011). The Consequences of the Post-Crisis Regulatory Architecture for Banks in Central Eastern Europe. Ekonomia, 2(14), 49-57.

Novickytė L., ir Saikevičius D. (2013). Susijungimu ir įsigijimu sandoriu globalioje rinkoje analizė. // Homo-societas-technologiae. 2013, Nr. 2, p. 63-71.

Novickytė, L. (2010). Bankų konsolidacijos procesas ir ịtaka finansų stabilumui. Mokslas - Lietuvos ateitis, 2:2, 62-68.

Novickyte், L. (2012). The effects of a new financial supervisory system on consolidation in banking sector. Вісник Кийвького національного університету імені Тараса Шевченка. Экономіка, 141, 26-30.

Novickytė, L., ir Jasienè, M. (2011). Banking Consolidation. Challenges and Prospects. Ekonomia, 2(14), 244-253.

Piesse, J., Lee, C.-F., Lin, L., and Kuo, H.-C. (2013). Merger and Acquisition: Definitions, Motives, and Market Responses. Esantis L. Cheng-Few, C. L. Alice, Encyclopedia of Finance (p. 411-420). New York: Springer. doi:10.1007/978-1-4614-5360-4

Podvezko, V. (2005). Agreement of Expert Estimates. Technological and Economic Developmentr of Economy, 11:2, 101-107.

Possible Effects of EMU on the EU Banking Systems in the Medium to Long Term. (1999). Frankfurt am Main: ECB.

Pukènas, K. (2009). Kokybiniy duomeny analizé SPSS programa: mokomoji knyga. Kaunas: Lietuvos kūno kultūros akademija.

Roll, R. (1986). The Hubris Hypothesis of Corporate Takeovers. Journal of Business, 59(2), 197-216.

Schinasi, G. J. (2010). Defining Financial Stability and Establishing a Framework to Safeguard It. Esantis R. A. Alfaro, Financial Stability, Monetary Policy, and Central Banking (p. 29-62). Santiago: Central Bank of Chile.

Stanikūnas, R. (2009). Konkurencijos politika: teorija ir praktika. Vilnius: TEV.

Stichele, M. (2008). Financial Regulation in the European Union: Mapping EU Decision Making Structures on Financial Regulation and Supervision. Brussels: EURODAD.

Uhde, A., and Heimeshoff, U. (2009). Consolidation in Banking and Financial Stability in Europe: Empirical Evidence. Journal of Banking and Finance, 33, 1299-1311. doi:10.1016/j.jbankfin.2009.01.006

\title{
COMPREHENSIVE ASSESSMENT OF DETERMINANTS OF MERGERS AND ACQUISITIONS IN THE BANKING SECTOR
}

\author{
Lina NOVICKYTĖ
}

Vilnius University, Faculty of Economics

\begin{abstract}
Globalization, consolidation among banks and the global financial crisis in recent decades have severely affected the banking sector. All of these changes have had an impact on the development of the sector and its stability. This paper examines factors and causes influencing the banking sector consolidation processes. In order to identify the motives, mergers and acquisitions in the banking sector and the potential impact of the consolidation to the financial system were driven. Based on the study results, a comprehensive matrix of mergers and acquisitions in the banking sector influencing factors, which include macro-, micro-elements and the importance of determining the value of the bank, was made.
\end{abstract}

Keywords: mergers, acquisition, banking sector, financial system. 